\section{El tránsito trunco hacia \\ la «República verdadera». \\ Yrigoyenismo, ciudadanía política \\ y territorios nacionales, 1916-1922}

Martha Ruffini
Martha Ruffini es Docente e Investigadora de la Universidad Nacional del Comahue.

e-mail: meruffini@speedy.com.ar

\section{Resumen}

El acceso del radicalismo al gobierno en 1916 fue visto como la apertura de una etapa de democratización e inclusión política del ciudadano. Empero, las contradicciones entre discurso y praxis de los principios republicanos, impidieron la consolidación del sistema democrático ocluyendo el camino hacia la «República verdadera». La decisión de mantener las limitaciones al ejercicio de la ciudadanía política de los territorios nacionales revelaría la continuidad de los aspectos más restrictivos del orden conservador y una modalidad de ejercicio del poder tributaria de los postulados fundacionales de la "República posible», que se evidenciaría al analizar la relación del yrigoyenismo con la gobernación de Río Negro entre 1916 y 1922.

Bajo este prisma, proponemos introducir la problemática territorial en los análisis vinculados con la debilidad democrática argentina y la presencia de rasgos autoritarios en el siglo XX. En ese sentido la cruzada democrática impulsada por el radicalismo tendría en la persistencia del formato territorial una clave de bóveda que nos permitiría introducir matices en las reflexiones e interpretaciones sobre la transición hacia la «República verdadera».
Una versión preliminar de este trabajo fue presentada en las XI Jornadas Interescuelas/Departamentos de Historia, Tucumán, septiembre del 2007. La autora agradece los comentarios de Cristian Buchrucker, Roberto Pucci y Luis Bonanno.

\section{Summary}

Radicalism's access to the government in 1916 was seen as the opening of a stage of democratization and citizen's political inclusion. But, the contradictions between speech and practice of the republican principles, impeded the consolidation of the democratic system occluding the road toward the "Real Republic».

The decision of maintaining the limitations to the political citizenship exercise of National Territories would revealed the most restrictive aspects of the conservative order and a way of exercising power tributary of the foundational postulates of the "Possible Republic». These aspects will be seen in the analysis of the Yrigoyenism relationship with Rio Negro's government between 1916 and 1922.

Under this prism, we propose to introduce the territorial problem in the research related with Argentinean democratic weakness and the presence of authoritarian features in the XX century. In that way the democratic crusade impulse by the radicalism would have, in the persistence of territorial format, a vault key which would allow us to introduce hues in the reflections and interpretations about the transition toward the "Real Republic». 